\title{
Abortion and Cultural Barbarism
}

\section{Magalhaes Filho GB*}

Professor and Master in Law, Federal University of Ceara, Brazil

*Corresponding author: Glauco Barreira Magalhaes Filho, Master in Law, Doctor of Sociology, Professor at the Faculty of Law of the Federal University of Ceara, Brazil, Email: glaucobarreira@ yahoo.com.br

\section{Mini Review}

Volume 4 Issue 3

Received Date: July 27, 2021

Published Date: September 01, 2021

DOI: $10.23880 / \mathrm{abca}-16000196$

\section{Abstract}

This article deals with abortion and its social consequences. The relativization of the value of the person and human life is criticized. Scientific positions on the beginning of life and the lack of a legal, scientific and philosophical foundation for the legalization of abortion are examined".

Keywords: Abortion; Society; Science; Law

\section{Mini Review}

As human nature is social, Natural Law could be seen as part of Political Law in a broad sense, that is, considered not only as a mere branch of Positive Law. The political nature comes from the same human nature which springs to life in society.

In a subjective sense, "right" is a term related to "obligation", thus assuming an interpersonal relationship. Individual rights, in particular, are opposed to the State. From the point of view of Positive Law, they would lose their meaning in a Totalitarian State, which engulfs society and instrumentalizes the individual.

Although natural rights are political in the broad sense (above), we also say that they predate the state. This is because the political entity is a unit of order (formed by relationships), with substantial unity only in individuals. Human nature brings out its own inclinations from particular people. There is, therefore, a logical precedence of individual rights in relation to the State. In this respect, they are pre-political.

We can define fundamental human rights as natural, pre-political and pre -state rights. They set the limits on state power, legislation and politics. They are inalienable, as they are not only subjective rights, but also objective values. If they are disqualified as natural and placed in the fluidity of the casuistry definition, they will not have a status distinct from other existing rights in the legal system. In this way, they will lose their guaranteeing function.

The right to life is the first of the fundamental rights (art. 5 of the Brazilian Constitution), as it is the condition for the existence of ALL others. To sacrifice one's life to safeguard someone else's inferior right is disproportionate, as it would be to sacrifice ALL the rights of the first in favor of some isolated right of the second.

The sacrifice of concrete human life in the name of collectivist perspectives is also Inadmissible. As we have seen, the State is a unit of order (relations) and only the individual is a substantial unit. We cannot sacrifice the substantial and primary unity in the name of the interests of the unity of order (secondary and derivative). Life in the abstract does not exist. It only exists in concrete human beings ("to live be to be"). We cannot protect it as a value without protecting concrete people at the same time.

A basic ontological principle is that "to be" is better than "not to be". All values depend on the existence of something to be valued. Thus, in BEING is the most basic value, the value 
of values, since NOTHING cannot be valued, adjective. Human life, in addition to being a physical good, is a moral good. The human being, from the womb, has a moral potential to be updated throughout its existence. If we classify physical evil as that which can hinder the development of the corporeal being, we will consider as moral evil that which can impede the development of the ethical being. To kill a child in the womb is to impede their physical development and the right to follow their own path towards moral perfection. Human life, due to its ethical destination, has an intrinsic dignity, being an end willed by it-self.

The social nature of man is responsible for the formation of the family (domestic society) and the state (political society). From the womb, the human being is already in the domestic society, he is already in a relationship. There is the relationship of the parents with the child (a) and, more directly, of the mother with the child (a). It is a relationship that involves the bodies of mother and baby in solidarity, but it is also a personal relationship. Both harms and psychological benefits can result from the fact that the person has been rejected or accepted in intrauterine life. Murdering a child in the womb is killing a human being, diminishing a family, taking a story from the world.

In the Bible, we have a passage in which God speaks of two children in Rebekah's womb as two peoples, which shows the prospective breadth of what is in a human being: "And the Lord said to him, There are two nations in your womb" (Genesis 25:23). The apostle Paul speaks of his vocation from the womb: "But when it pleased God, who separated me from my mother's womb, and called me by his grace" (Galatians 1:15). Lucas records John the Baptist's interaction with his mother in the womb: "And it so happened that, when Elizabeth heard Mary's greeting, the little child jumped into her womb; and Elizabeth was filled with the Holy Spirit" (Luke 1:41). The psalmist speaks of man related to God from the womb: "I was cast upon thee from the womb, thou art my God from the womb of my mother" (Psalm 22:10). W. Liley, research professor of fetal physiology in Auckland, New Zealand, known as the "Father of Fetal Medicine," noted that "the fetus is not a passive vegetable" but a dynamic human being as it organizes the mother, as well as decides when to start labor [1].

Life starts from conception, as everything develops from what is already there, there is no third element besides the sperm and the egg to come together to have the zygote. Abortion, therefore, is a violation of the right to life and the right to be born. It is a murder with several aggravations.

- First, because committed with the consent of the mother, who should be the child's greatest protector.

- Second, because it is a crime committed against an innocent in a vulnerable position.

- Third, because the act is performed with cruelty, with no possibility of defense or escape for the victim.

It is indefensible from an ethical or humanitarian point of view.

Dr. Alfred Bongiovanni of the University of Pennsylvania School of Medicine noted: "Standard medical texts have long taught that life begins at conception." Dr. Watson A. Bowes Jr. of the University of Colorado School of Medicine, acknowledging conception as the beginning of life, added that "this simple biological fact should not be distorted to serve sociological, political, or economic purposes" [2]. The International Code of Medical Ethics states: "A physician must always bear in mind the importance of preserving human life from conception to death" [1].

Many try to say that the fetus is a living human being, but not a person. Those who use this strategy never understand what a person is, getting lost in subjective philosophical speculations. At that moment, the such are not at all "scientific". The "Oxford American dictionary" (Dictionary American Oxford) and "Webster's Third International Dictionary of the Inglês Language" (Third International Dictionary Webster's English Language), however, are objective, defining "person" simply as "A HUMAN INDIVIDUAL". The fetus, therefore, is not just a possibility of being a person (a potential person), but it is a person defined in all its biological development.

Nancy Jo Mann, founder of the organization "Women Exploited by Abortion" (WEBA), revealed how, as a young woman, she was advised to have an abortion, without being informed of the physical and psychological risks, as well as being deceived by the use of several euphemisms that avoided the knowledge that a human life was being sacrificed. For her, it was only said that she would get rid of a "problem". But when the saline solution was introduced and it began to burn the baby's skin, she felt inside herself a human being struggling for survival [1].

Feminism, in its current version, to the military for the decriminalization of abortion in the name of women's emancipation, is fallacious. Feminists say that a woman's body, in its reproductive functions, puts her at a disadvantage when compared to men. They encourage lesbianism, while lamenting the typically feminine characteristics, seeking in masculinization the reference of their progress. All this, however, does not elevate the woman, but despises the feminine. It is, therefore, a new version of machismo.

When feminists advocate abortion in the name of women's rights, they omit that $50 \%$ of aborted babies are their own sex. On the other hand, these same feminists protest 
against the selective and preferential abortion of female babies in the East. They also ignore discursive manipulation to convince women to have abortions in clinics led by doctors who are mostly men. The physical and psychological damages (depression, suicide) caused to the woman by the abortion practice are also deliberately omitted. Women need to be valued in their feminine peculiarities, and motherhood is a great privilege. The true dignity of women lies in what the Brazilian Constitution calls "maternity protection" (art. 6, art. 201, II, 203, I, of the Brazilian Constitution) and not in the legalization of abortion. Protecting motherhood is protecting a relationship with two sides (mother and child). A mother cannot avoid motherhood by aborting, as she is already a mother from the moment she conceived. On the other hand, you cannot protect motherhood by destroying it.

\section{The Baby and the Mother: Two Lives, Two People}

Many defend the practice of murdering unborn children, stating that abortion is nothing more than the exercise, by the mother, of the right to free disposition of the body. For such people, the fetus would be a mere extension of the mother's body. The truth, however, is that the fetus has a different life from the mother.

The fact that the child in her mother's womb may have a different blood type is sure proof that she is a foreign body in the woman's womb. It is impossible for a single individual to have two different blood types. The child would be rejected by the mother's body were it not for the protection offered by the placenta. The zygote starts producing the placenta aiming at its own protection after 72 hours of existence. Thus, the fetus organizes its own mother, in which case the mother appears as its passive dependent. It is also the fetus, not the mother, who decides when to start labor.

The embryo's independence is also revealed in the fact that, being transported to a womb different from the one in which it was conceived, it does not assimilate the characteristics of the woman who receives it.

The child in the womb also has its own fingerprints and may have a different sex than the mother. If a male baby, while in the mother's womb, were part of her body, would the mother then have two sexes? Was it hermaphrodite?

Abortion is talked about as a woman's right, but nobody remembers that many of the aborted children are women!

Ultrasound technology has revealed that the baby in the womb is an autonomous person. Dr. Bernard Nathanson, known as the "Abortion King" (over 60,000 abortions performed), radically changed his pro-abortion stance by learning more about the fetus in the womb through modern technology. On the other hand, no one can deny the embryo the status of a person, for no living human body can "become" a person unless it is already one. Only artifacts (clocks, walls, cars, etc.) come into being in parts. Living beings appear at once and gradually reveal themselves to them-selves and to the world.

In 1973, the United States Supreme Court ruled that the beginning of life was a "difficult question", although virtually every textbook on medicine and biology up to that time assumed that human life began at conception. From that perspective, the Supreme Court ruled in favor of abortion, without giving life the benefit of the doubt.

Two years before the US Supreme Court decision (Roe versus Wade), 220 renowned physicians, scientists and professors delivered a document to the Supreme Court, showing that modern science had already defined conception as the beginning of the human person and that the human life is an ongoing process. Patrick A. Trueman, who helped prepare a summary for an Illinois state judgment on the unborn child, said a medical professor's testimony detailing 19 textbooks on the subject of embryology used in medical schools in Illinois was included. Today it is universally agreed that life begins at conception, but the court ignored it [3].

As for the fact that the embryo is a person, just remember that the human being, in the intrauterine period, is influenced by the feeling of the parents (especially the mother) in relation to themselves, as well as the treatment of others towards their mother. These circumstances act in a decisive way in the formation of temperament and unconscious memory. Dr. McCarthy De Mere, who is both a clinician and a professor of law at the University of Tennessee, has stated that the exact moment of the beginning of being a person and of the human body is the moment of conception [2]. Dr. Jerome Lejeune, Professor of Fundamental Genetics at Descartes University (Paris), also said that each individual has a very unique beginning, the moment of conception [2].

It is the physician's moral duty to be against abortion. The International Code of Medical Ethics states: "A physician must always bear in mind the importance of preserving human life from conception to death". The Geneticist Declaration charges physicians with the following: "I will have the utmost respect for human life from the moment of conception; even under threat, I will not use my medical knowledge in a way contrary to the laws of humanity" [4].

What we see happening now in the Western world, however, is the advance of a corrosive principle that degrades everything that is human: life, childhood, the biological distinction between the sexes, motherhood, family 
authority, etc. Therefore, it is important that we consider the widespread evil that has been spreading in Western culture.

\section{Man's Swimming and Death}

Nietzsche announced the "death" of God in the West, predicting man's death as its consequence. What the "prophet of Nazism" ("the goal is not humanity, but Superman") meant that the Western conception of man was directly linked to theism [5].

In the West, the Judeo-Christian belief in the presence of the image of God in man had many consequences. From a religious point of view, she recognized the immortality of the soul and the moral law inscribed in the conscience. From a philosophical point of view, it made the difference between man and animal to be qualitative and not merely quantitative. In the legal field, it enabled the development of the idea of human dignity and fundamental rights.

The decline of Christian influence in the West, called the "death of God" by Nietzsche, is producing the "death" of man as we know it. The human being is seen as a result of chance, of selective evolution. His distinction from the animal is now seen as quantitative (greater complexity) and not qualitative. Within this scope, the soul is reduced to the brain and freedom becomes an illusion. Morality starts to be seen as oppression and the free expression of instincts comes to be recommended. There is no longer a radical reason to speak of human dignity, while fundamental rights are considered just a creation of Western culture.

After talking about the Judeo-Christian contribution to the formation of the dignity of the human person, Pitirim A. Sorokin shows another vision of man that has been developing in the West:

"Unfortunately, this gleaming facade is not the only aspect of our cultural and social building. Like the mythical two-faced Janus, she has another, more sinister face, the face of a great degradation and dehumanization of man; of lowering, altering and debasing all social and cultural values. If the glittering facade glorifies man as a divine hero, the second face strips him of all the divine and heroic. If one of the faces of our culture shows it as a creative flame of human genius that rises ever higher-'per aspera ad astra'-to the eternal world of absolute values, its second face mocks such an illusion and lowers it to level of mere reflex tingling, to the simple 'adjustment mechanism' of human ants and bees.

We don't like to flaunt this sinister face of our culture, which doesn't show up at any World's Fair, but which nevertheless is as certain as solid fact can be. Even more, with the passage of time, as we have seen, it appears more and more frequently, and it tends progressively to cloud the bright aspect of our cultural world..." [6].

Man is no longer characterized by the desire for truth to be identified in all his acts by the desire for power. Thus, the "truth" becomes a metaphor to designate a strategy of domination, a convenience or a mere convention, making the reason for existence of science and philosophy die. As Pitrim A. Sorokin said, man goes from being a sublime researcher of truth as an absolute value to a hypocrite who uses "truth" as a "beautiful smokescreen to justify his impulses and greed, profit and voracity" [6].

With the death of the Christian conception of man, a culture of destruction arises. Philosophy turns into deconstructivism, while truth and goodness lose their meaning. Human life is deprived of its value and abortion, together with euthanasia and assisted suicide, are ardently defended. Dietrich Bonhoeffer watched this happen in Nazism and called this process "nadification", saying that nothingness presents itself as creative as God, despite only devouring the inner coming, leaving only a dead shell in the end [7].

From the line of reasoning assumed by the Jewish philosopher Hans Jonas, we can infer that the moral law requires greater protection for the weakest, noting that human life is more fragile in the seminal and terminal phases. Thus, the embryo and the old are the ones that most need protection. Today's society, however, having reduced the human to the animal level, can justify the stronger destroying the weaker, just as the wolf does the sheep.

This "nadified" society is not bothered by contradictions, as logic is also seen as a Western invention or a surmountable product of the course of evolution. Thus, feminists advocate widespread abortion in the West, but fight selective abortion of female children in the East. An American association sees no contradiction between its apology for abortion and its fight against the killing of seal pups. England does not realize that, by discarding thousands of frozen human embryos, it is carrying out a collective genocide as serious as those that took place in Nazi Germany and Africa.

Now, the crippled and disabled are seen as a social burden. In Europe, eugenic abortion has been practiced and children born with certain anomalies have been mercilessly sacrificed at birth. It is not surprising that in this decadent Europe the trafficking of foreign women into slavery in the sex market is also on the rise, while in the Third World slave labor is proliferating on large plantations.

Heinrich Heine and Carl Jung announced that the decline of Christianity in Germany would awaken the barbaric and pagan spirit of the ancient Germans. That's what happened 
through Nazism. Today, we see television show wrestling tournaments with the celebrations of the population. Fights are much more violent and bloodthirsty than boxing. We are seeing a return to the gladiators of Roman paganism.

Finally, I would like to talk about extreme sports, which make danger fun, stimulating the adrenaline for the approach of misfortune. Here, we must remember that Satan tempted Jesus in the wilderness, inviting him to jump from a high place based on the promise that the angels would not allow him to trip over any stone. Jesus, however, replied, "Thou shalt not tempt the Lord thy God!“.

In Charles Dickens' "Memoirs of Pickwick" the wise and good Samuel Pickwick says:

"My friend - said Pickwick - I love all sporting competitions, harmless and lawful, where there is no danger to human life, which is the most precious of gifts" [8].

During Nazism, the Lutheran theologian Dietrich Bonhoeffer observed that those who defended life in Germany (within a humanitarian vision) spontaneously approached the Christian church. In those dying hours, Christianity offered a higher and more dignified view of all human beings [7].

To get out of "nadification" we have to go back to the sources that gave vitality to Western Culture.

\section{The Legalization of Abortion is the Path to Barbarism}

The news Dickens C [8] that the Federal Council of Medicine, by a majority, manifested itself in favor of abortion until the third month of pregnancy caused a profound reaction in Brazilian society. The indignation became greater because they are professionals who take care of life and took an oath to preserve it. Seeing them instrumentalized by dangerous political ideologies creates deep discomfort. It is the typical allegiance of intellectuals or professionals in relation to power, something typical of authoritarian regimes.

From a practical point of view, the position taken is anachronistic. After so many methods of child avoidance have been invented, returning to discuss murder after conception is a complete step backwards. The culture of death, however, is also the culture of materialism and hedonism. Children can be sacrificed so they won't be a burden on the parent's budget. Abortion becomes the fastest way out for those who do not want to have a "deficit" of pleasure in sexual intercourse through the use of condoms, or even for women who want to avoid the discomforts resulting from the use of contraceptive pills.
The legalization of abortion is the return of barbarism. The next step is to accept cannibalism. And for those who think I'm exaggerating, I recommend listening to the words of famous abortionist Peter Singer:

"The mentally defective have no right to life and can therefore be killed for food-if we were to develop a taste for human fleshor for the purpose of scientific experimentation" [1].

Peter Singer also said that "weakly mental babies have no greater rights than those of certain animals" (Independent Extra-September 13, 2006). Bill Hamilton, renowned Darwinian biologist and abortion advocate, said he had more sympathy for a fern than a crying child, while David Robertson said the following about Hamilton:

"He argued that males were greatly destined to compete and that the purpose of sex was to cleanse the population's gene pool by filtering out the useless and the weak. The low condition male is better off dead. Everything in nature, according to Hamilton, could be explained as a result of gene competition. He advocated a radical program of infanticide, eugenics, and euthanasia in order to save the world. He believed that modern medicine was doing harm by allowing the weak to survive, thus preserving their genes" [9].

William Brennan said the following words: "Although every holocaust once committed is an unprecedented event in its own right, this should not diminish what all holocausts have in common...the systematic and widespread destruction of millions seen as indiscriminate masses of scathing subhumans. "The cultural environment for a human holocaust is present whenever any society goes astray and defines individuals as less than human and therefore devoid of value and respect" [10].

It is urgent that we return to a position against barbarism that we return to a humanitarian position!

\section{Conclusion}

$>$ We conclude that life begins at conception and that there is no human life that is not personal.

$>$ We recognize that the right to life is the first of human rights and those natural rights are non-negotiable in the political sphere.

$>$ We identified the emergence of a culture of death and nadification, which reduces man to animality, subtracting his intrinsic dignity and creating disposability of the weakest.

$>$ The culture of death leads to barbarism and destroys the humanizing results of civilization.

$>$ The defense of life must correspond to the defense of the culture in which it gained value and respect. 


\section{References}

1. John A, John W (1999) The facts about abortion. Trans. Eros Pasquini. $2^{\text {nd }}$ (Edn.), Porto Alegre: Call of Midnight, pp: 17-39.

2. Landrum SB (1983) Rites of Life: The Scientific Evidence for Life before Birth. Grand Rapids, MI: Zondervan, pp: 114.

3. (1982) Television program transcribed. Abortion, Chattanooga, TN, The John Ankerberg Evangelistic Association, pp: 2.

4. (1949) These statements can be found in the World Medical Association Bulletin.

5. Abir T (2007) Nietzsche, Prophet of Nazism: The Cult of Superman, Revealing the Secret Nazi Doctrine. Trans.
Caroline Furukawa. São Paulo: Madras.

6. Pitirim SA (1945) The Crisis of Our Time. Trans. Alfredo Cecílio Lopes. São Paulo: University Publisher, pp: 217218.

7. Dietrich B (1995) Ethics. $3^{\text {rd }}$ (Edn.), Trans. Helberto Michel. São Leopoldo: Sinodal, pp: 63

8. Dickens C (1970) Pickwick Memories. Trans. Origen Lessa. Rio de Janeiro: Ediouro, pp: 30.

9. David R (2009) Letters to Dawkins. Trans. Vanderson Moura da Silva. Brasilia: Monergism, pp: 116.

10. William B (1980) Medical Holocausts: Exterminative Medicine in Nazi Germany and Contemporary America. Boston, MA: Nordland Pub. International, Inc 1: 68. 